\title{
The Influence of Modeling Techniques and Motivation Learning against Writing Skills of Student News Text of Class VIII SMP Negeri 3 Padang
}

\author{
Novritika ${ }^{1}$, Harris Effendi Thahar ${ }^{2}$, Irfani Basri ${ }^{3}$ \\ ${ }^{123}$ Universitas Negeri Padang, Padang - Indonesia, (novritika.1024@gmail.com)
}

\begin{abstract}
This study aims to describe the influence of modeling techniques and learning motivation to the news text writing skills of students. This research used quantitative with the $2 \times 2$ factorial experimental design. The Sample in this research is 60 students. The instruments used motivation inventory to learn and performance inventory. The results from this study are: First, there are differences among the results of text-writing skills taught by modeling techniques with the results of text-writing skills taught by conventional techniques. Secondly, there are differences as the result of writing skill of news text of students who have high learning motivation with students who have low learning motivation. The result of writing skill of news text of students who have higher learning motivation is higher than students who have low learning motivation. Third, there is no interaction between modeling techniques and learning motivation in influencing the ability to write news text.
\end{abstract}

Keywords: modeling techniques, learning motivation, skill writing news text

This is an open access article distributed under the Creative Commons 4.0 Attribution License, which permits unrestricted use, distribution, and reproduction in any medium, provided the original work is properly cited. (2018 by author and Faculty of education, Universitas Negeri Padang.

\section{Introduction}

Writing activities can not be separated from how students improve their writing skills. This is evidenced in the research of Antonio (2011), Fatima (2012), Sajid (2015) which states that improving and teaching students writing skills is very important for the current era. In addition, some things related to the ability to write students is the ability of the students themselves, as evidenced in the research Mousapour (2011) which states that students who are aware of his ability to write will maximally develop the potential in him. With good writing skills, one can disseminate his thoughts, views, opinions, ideas or feelings about things productively, interestingly and easily understood. However, writing skills are the most difficult language skills to master because writing is a very complex cognitive process (Sibarani, 2007).

One of the texts that the VIII students should learn in the 2013 curriculum is the news text. In this case, students are required to be able to understand to compose text of news both oral and written. Writing news texts is in the 4th Core Competence (KI), which is "Trying, processing, and serving in a concrete realm (using, parsing, stringing, modifying, and making) and abstract (writing, reading, counting, drawing, and authored) in accordance with what is studied in school and other sources in the same perspective / theory ", and the 3rd Basic Competence (KD) is" Reviewing the structure and 
language of the news text (pride and motivation) heard and read the news, "and Basic Competence (KD) to 4 is "Presenting data, information in the form of news orally and write with attention to structure, linguistic, or oral aspects (pronunciation, intonation, mimic, kinesik)".

Based on the problems that have been described, then needed a solution to overcome them. One of the techniques that can be used in learning writing, especially writing news text is to use Modeling Technique. Modeling technique is one way to improve students' ability in learning process. So that students can be skilled in writing. Suluk on the results of research conducted by Satini (2004), that there is a significant relationship between learning motivation and writing skills. Learning motivation contributes positively to writing skills.

Based on the problems that have been described, researchers feel the need to do research on the influence of modeling techniques and motivation to learn the skills to write news text of students of class VIII SMP Negeri 3 Padang. SMP Negeri 3 Padang chosen as the object of research because based on observations made, students of class VIII SMP Negeri 3 Padang not skilled in writing news texts. This is because they have a lot of problems in writing, so it takes a solution to overcome these problems by using modeling techniques to facilitate students in writing news texts. Modeling techniques are expected to realize the competence of students to be better, especially in learning to write news text. Researchers want to know whether there is a significant influence of the use of modeling techniques and motivation to learn the skills to write news text of students of class VIII SMP Negeri 3 Padang through research entitled Influence of Modeling Techniques and Motivation Learning of Text Writing Skills News Class VIII SMP Negeri 3 Padang.

\section{Method}

This type of research is quantitative research because in this study data are processed numbers. Figures in this study are the score and the value of questionnaire motivation to learn and the value of the final test of skills to write news text of students of class VIII SMP Negeri 3 Padang. This is in line with the opinion Sugiyono (2012: 14) which states that quantitative research is a research technique based on the philosophy of positivism used to examine the population and specific samples, sampling techniques are generally done randomly. The collection is quantitative or statistical in order to test the predefined hypothesis.

The population in this study were students of class VIII SMP Negeri 3 Padang registered in the academic year 2016/2017 consisting of 5 classes of class VIII.1, VIII.2, VIII.3, VIII.4, and VIII.5 which amounted to 150 person. Classes are determined as a sample of research, conducted purposive sampling technique. According to Arikunto (2008: 139), purposive technique is done by taking the subject is not based on strata, random or regional but based on the existence of a particular purpose. This technique is done because of some considerations, such as the reasons for limited time, energy, and funds so it can not take large and far samples. Obtained class VIII.1 (experimental class) as many as 30 people and class VIII.2 (control class) as many as 30 people.

The technique used in this research is experimental technique. This type of experiment is a quasi experiment. According to Suryabrata (2011: 92) the quasy experiment aims to obtain information that is an estimate for information that can be obtained with actual experiments in circumstances that are not possible to control and manipulate all relevant variables. This research design using factorial design design (2x2). Factorial design is the most efficient design to investigate the effects of two or more factors (Suwanda, 2011: 145). Technique of data analysis conducted in this research is as follows. (1) data analysis of learning motivation, (2) data analysis of news text writing skill. 


\section{Results}

Data Analysis Motivation Student Learning

The data of students' learning motivation in the study were obtained through questionnaire of choice type with ordinal with five alternative answers Always (SL), Frequently (SR), Sometimes (KD), Rarely (JR), and Never (TP). Furthermore the acquisition of questionnaires test students' motivation motivation is divided into high and low group with the provisions of $27 \%$ and above with high category and $27 \%$ down including in low category. The highest score for the students' motivation test on the experimental class was 160 and the lowest score was 118. Whereas, the highest score for the student's motivation test on the control class was 152 and the lowest score was 120.

Data Results Student Motivation Questionnaire Motivation in Experimental Class

Based on the questionnaire of student learning motivation in the highest score experimental class for the group of students who have high learning motivation is 160 and the lowest score is 147 . For more details see the table below.

Table 1. Student Group Table with High Learning Motivation in the Experimental Class

\begin{tabular}{llll}
\hline \multirow{2}{*}{ No } & \multicolumn{2}{l}{ Experiment } & Information \\
\cline { 2 - 3 } & Sample & Score & \\
\hline $\mathbf{1}$ & $\mathbf{2}$ & $\mathbf{3}$ & $\mathbf{4}$ \\
\hline $\mathbf{1}$ & E-20 & 160 & \multirow{2}{*}{ High Learning Motivation } \\
\hline $\mathbf{2}$ & E-04 & 157 & \\
\hline $\mathbf{3}$ & E-15 & 157 \\
\hline $\mathbf{4}$ & E-22 & 156 \\
\hline $\mathbf{5}$ & E-29 & 153 \\
\hline $\mathbf{6}$ & E-30 & \multicolumn{1}{|}{150} \\
\hline $\mathbf{7}$ & E-10 & 149 \\
\hline $\mathbf{8}$ & E-28 & 147 & \\
\hline
\end{tabular}

Next, the highest score for groups of students who have low learning motivation in the experimental class is 124 and the lowest score is 118. For more details see the table below.

Tabel 2. Kelompok Siswa yang Memiliki Motivasi Belajar Rendah pada Kelas Eksperimen

\begin{tabular}{|c|c|c|c|}
\hline \multirow[t]{2}{*}{ No } & \multicolumn{2}{|c|}{ Experiment } & \multirow[t]{2}{*}{ Information } \\
\hline & Sample & Score & \\
\hline 1 & 2 & 3 & 4 \\
\hline 1 & E-26 & 124 & Low Learning Motivationt \\
\hline 2 & E-02 & 123 & \\
\hline 3 & E-16 & 123 & \\
\hline 4 & E-07 & 122 & \\
\hline 5 & E-24 & 121 & \\
\hline 6 & E-25 & 120 & \\
\hline 7 & E-27 & 119 & \\
\hline 8 & E-08 & 118 & \\
\hline
\end{tabular}


Data Results Student Motivation Questionnaire in the Control Class

Based on the questionnaire of student learning motivation in the control class, the highest score for the group of students who have high learning motivation is 152 and the lowest score is 149. For more details see the table below.

Tabel 3. Student Group Table with High Learning Motivation in Control Class

\begin{tabular}{llll}
\hline \multirow{2}{*}{ No } & Control & \multicolumn{2}{c}{ Information } \\
\cline { 2 - 3 } & Sample & Score & \\
\hline $\mathbf{1}$ & $\mathbf{2}$ & $\mathbf{3}$ & $\mathbf{4}$ \\
\hline $\mathbf{1}$ & K-25 & 152 & \multirow{2}{*}{ Hight Learning Motivation } \\
\hline $\mathbf{2}$ & K-02 & 151 & \\
\hline $\mathbf{3}$ & K-20 & 150 \\
\hline $\mathbf{4}$ & K-24 & 150 \\
\hline $\mathbf{5}$ & K-29 & 150 \\
\hline $\mathbf{6}$ & K-23 & 150 \\
\hline $\mathbf{7}$ & K-04 & 149 \\
\hline $\mathbf{8}$ & K-06 & 149 \\
\hline
\end{tabular}

Next, the highest scores for groups of students with low learning motivation in the control class were 131 and the lowest score was 120. For more details note the table below.

Table 4. Student Group Table with Low Motivation in Control Class

\begin{tabular}{|c|c|c|c|}
\hline \multirow[t]{2}{*}{ No } & \multicolumn{2}{|c|}{ Controle } & \multirow[t]{2}{*}{ Information } \\
\hline & Sample & Score & \\
\hline 1 & 2 & 3 & 4 \\
\hline 1 & K-01 & 131 & Low Learning Motivation \\
\hline 2 & K-05 & 131 & \\
\hline 3 & K-08 & 131 & \\
\hline 4 & $\mathrm{~K}-10$ & 129 & \\
\hline 5 & $\mathrm{~K}-15$ & 128 & \\
\hline 6 & $\mathrm{~K}-17$ & 125 & \\
\hline 7 & K-03 & 121 & \\
\hline 8 & K-16 & 120 & \\
\hline
\end{tabular}

Data Analysis of Test Results of Student Text Writing Skills Skills

As a preliminary illustration in this section, the following will be described in detail about the data writing skills test results of VIII class VIII SMP Negeri 3 Padang students for the experimental class and control class.

Results of Writing Skills of Student News Text in Experiment Class

Based on the results of the analysis of text writing skills in the experimental class, it can be explained that the average value for the experimental class is 80.75 with the number of students as much as 16 people. The maximum value that students get in the experimental class is 92.00 with a frequency of 1 person while the minimum value for the experimental class is 62.00 with a frequency of 1 person. Meanwhile, standard deviation in the experimental class is 8.97. For more details see the table below. 
Table 5. Experimental Text Writing Text Writing Skills

\begin{tabular}{lllllll}
\hline No. & Class & Highest Value & Lowest Value & $\mathrm{X}$ & $\mathrm{N}$ & $\mathrm{S}$ \\
\hline $\mathbf{1}$ & $\mathbf{2}$ & $\mathbf{3}$ & $\mathbf{4}$ & $\mathbf{5}$ & $\mathbf{6}$ & $\mathbf{7}$ \\
\hline $\mathbf{1}$ & Exsperiment & 92.00 & 62.00 & 80.75 & 16 & 8.97 \\
\hline
\end{tabular}

Results of Student Text Writing Skills on the Control Class

Based on the results of the analysis of news text writing skills conducted in the control class can be described that the average value for the control class is 74.50 with a total of 16 students. Maximum value obtained by students in the control class is 85.00 with a frequency of 2 people while the minimum value for the control class is 65.00 with a frequency of 1 person. Meanwhile, the standard deviation in the control class is 7.57. For more details see the table below.

Table 6. Writing Skills for News Text Class Writing Skills

\begin{tabular}{lllllll}
\hline No. & Class & $\begin{array}{l}\text { Highest } \\
\text { Value }\end{array}$ & $\begin{array}{l}\text { Lowest } \\
\text { Value }\end{array}$ & X & N & S \\
\hline $\mathbf{1}$ & $\mathbf{2}$ & $\mathbf{3}$ & $\mathbf{4}$ & $\mathbf{5}$ & $\mathbf{6}$ & $\mathbf{7}$ \\
\hline $\mathbf{1}$ & Control & 85,00 & 65,00 & 74,50 & 16 & $\mathbf{7 , 5 7}$ \\
\hline
\end{tabular}

Data Distribution Test Writing Skills Text News with Data Student Motivation Questionnaire

Based on the test of news text writing skill and motivation questionnaire score of students of grade VIII SMP Negeri 3 Padang, will further describe the distribution of the value of text writing skills and test score of students' learning motivation in the experimental class and control class.

Results Writing Text News Students Who Have High Learning Motivation in Experiment Class

The result of the test of writing skill of news text of students who have high learning motivation conducted in the experimental class can be described that the average score for students who have high learning motivation in the experimental class is 82,38 with the number of students as many as 8 people. Maximum value obtained by students is 92.00 with a total of 1 person while the minimum value is 67.00 amounted to 2 people and standard deviation is 9.00 . For more details see the table below.

Table 7. Results Test Text Writing News Students Who Have High Learning Motivation in Experiment Class

\begin{tabular}{lllllll}
\hline No. & Class & Highest Value & Lowest Value & X & N & S \\
\hline $\mathbf{1}$ & $\mathbf{2}$ & $\mathbf{3}$ & $\mathbf{4}$ & $\mathbf{5}$ & $\mathbf{6}$ & $\mathbf{7}$ \\
\hline $\mathbf{1}$ & Exsperiment & 92,00 & 67,00 & 82,38 & 8 & 9,00 \\
\hline
\end{tabular}

Results Writing Text News Students Who Have Low Learning Motivation in Experimental Class

Based on the result of the test of writing skill skill of news text of students who have low learning motivation conducted in the experimental class can be described that the average score for students who have low learning motivation in the experimental class is 79.13 with the number of students as many as 8 people. Maximum value obtained by students is 91.00 amounted to 2 people while the minimum value is 62.00 amounted to 2 people and standard deviation is 9.23 . For more details see the table below. 
Table 8. Results Test Text Writing News Students Who Have Motivation Learning Low Class Experiments

\begin{tabular}{lllllll}
\hline No. & Class & Highest Value & Lowest Value & $\mathrm{X}$ & $\mathrm{N}$ & $\mathrm{S}$ \\
\hline $\mathbf{1}$ & $\mathbf{2}$ & $\mathbf{3}$ & $\mathbf{4}$ & $\mathbf{5}$ & $\mathbf{6}$ & $\mathbf{7}$ \\
\hline $\mathbf{1}$ & Exsperiment & 91,00 & 62,00 & 79,13 & 8 & 9,23 \\
\hline
\end{tabular}

Results Writing Text News Students Who Have High Learning Motivation in Control Class

The result of the test of writing skill of news text of students who have high learning motivation conducted in the control class can be described that the average score for the students who have high learning motivation in the control class is 73,75 with the number of students as many as 8 people. Maximum value obtained by students is 85.00 amounted to 2 people while the minimum value is 65.00 amounted to 1 person and standard deviation is 9.11. For more details see the table below.

Table 9. Results Test Text Writing News Students Who Have High Learning Motivation Class Control

\begin{tabular}{lllllll}
\hline No. & Class & Highest Value & Lowest Value & X & N & S \\
\hline $\mathbf{1}$ & $\mathbf{2}$ & $\mathbf{3}$ & $\mathbf{4}$ & $\mathbf{5}$ & $\mathbf{6}$ & $\mathbf{7}$ \\
\hline $\mathbf{1}$ & Control & 85,00 & 65,00 & 73,75 & 8 & 9,11 \\
\hline
\end{tabular}

Results Writing Text News Students Who Have Low Motivation Learning in Control Class

Based on the result of the test of writing skill skill of news text of students who have low learning motivation that is implemented in the control class can be described that the average score of students who have low learning motivation for the control class is 75.25 with the number of students as many as 8 people. Maximum value obtained by control students is 83.00 amounted to 1 person while the minimum value is 67.00 amounted to 1 person. Meanwhile, standard deviation is 8.21 . For more details note the tebel below.

Table 10. Results Test Text Writing News Students Who Have Low Motivation Learning in Control Class

\begin{tabular}{lllllll}
\hline No. & Class & Highest Value & Lowest Value & X & N & S \\
\hline 1 & $\mathbf{2}$ & $\mathbf{3}$ & $\mathbf{4}$ & $\mathbf{5}$ & $\mathbf{6}$ & $\mathbf{7}$ \\
\hline $\mathbf{1}$ & Control & 83,00 & 67,00 & 75,25 & 8 & 6,21 \\
\hline
\end{tabular}

\section{Discussion}

This discussion is described in three main subjects related to the theories that have been put forward in the previous section, namely (1) students 'text writing skills taught by using modeling techniques and conventional learning models, (2) students' high motivation writing skills with the skills to write news text students who have low learning motivation, and (3) the interaction between learning motivation and modeling techniques in influencing the skills of writing news text.

Writing Skills Text News Students Taught By Using Modeling Techniques and Conventional Learning Techniques

The results of the first hypothesis testing revealed that the overall writing skill of group news text of students using modeling technique is higher than the students' news text writing skills using conventional learning techniques. Result of calculation which have been done by using $\mathrm{F}$ test or two way analysis of variance obtained Fcount $(\mathrm{A})=29,85>\mathrm{Ftable}=4,20$ then $\mathrm{H} 0$ is rejected, it means there 
is difference of result of writing skill of news text of student taught by modeling techniques with the results of students' text-writing skills taught by conventional techniques. The one-party test, calculated by the formula: fcount $(\mathrm{A}) \Rightarrow$ ftable $(0.05: 32)=1.67$ or $\mathrm{H} 0$ is rejected. So that the result of writing skill of news text of student who is taught by modeling technique is higher than result of student's news text writing skill which is taught by conventional technique. In this case the average of the experimental group is 80.75 while the control group is 74.5

Based on the findings and data analysis conducted it can be concluded that there is influence modeling techniques to students' text writing skills. This is evidenced from the results of the test writing text news students experiment class higher than the control class students. The experimental class students were given treatment in the form of modeling techniques while the control class used conventional learning.

Text Writing Skills News Students Who Have High Learning Motivation with Text Writing Skills News Students Who Have Low Motivation Learning

The results of the second hypothesis test show that the skills of writing news text students who have high learning motivation are taught with modeling techniques higher than students who have high learning motivation that is taught by conventional learning techniques. Differences in the skills of both classes, experimental classes and control classes, with high learning motivation levels can be seen from the average score of different news text writing skills. Overall, students who have high learning motivation in the experimental class gain the value of news text writing skills above the $\mathrm{KKM}$. This is due to the effect of the treatment applied to the experimental class. However, unlike the control class that uses conventional learning techniques. The average student in the control class more does not reach above the KKM. Although there are also some students who achieve value above KKM.

Based on the findings and data analysis conducted it can be concluded that there is influence modeling techniques to students' text writing skills. This is evidenced from the results of the test writing text news students experiment class higher than the control class students. The experimental class students were given treatment in the form of modeling techniques while the control class used conventional learning.

Text Writing Skills News Students Who Have High Learning Motivation with Text Writing Skills News Students Who Have Low Motivation Learning

The results of the second hypothesis test show that the skills of writing news text students who have high learning motivation are taught with modeling techniques higher than students who have high learning motivation that is taught by conventional learning techniques. Differences in the skills of both classes, experimental classes and control classes, with high learning motivation levels can be seen from the average score of different news text writing skills. Overall, students who have high learning motivation in the experimental class gain the value of news text writing skills above the KKM. This is due to the effect of the treatment applied to the experimental class. However, unlike the control class that uses conventional learning techniques. The average student in the control class more does not reach above the KKM. Although there are also some students who achieve value above KKM.

Interaction between Learning Motivation and Modeling Techniques in Influencing Text Writing Skills News

Results of two-way anova calculations for testing the fourth hypothesis concluded that there is no interaction between modeling and conventional techniques with high and low learning motivation of students in influencing students' text writing skills. As has been stated previously that interaction is 
the effect of treatment of certain learning approaches to groups of students who have a certain learning motivation. However, the motivation of student learning may not necessarily determine success in news text writing skills. Many other factors that influence such as motivation, intelligence, ability, talent, interest, learning environment, and so forth. In this research the main factor affecting the result of writing skill of student's news text is modeling technique. This is due to learning motivation and modeling techniques running independently. In addition, teacher readiness factor becomes a determinant of the success of student learning outcomes.

There is no interaction between modeling techniques with student learning motivation can also be seen from the average test results writing text news skills. This happens on both levels of learning motivation, both of which have high or low learning motivation that are equally taught using modeling techniques. The average value of text writing skill of students who have high and low learning motivation in the experimental class is higher than those who have high and low learning motivation in the control class.

Based on the result of the third hypothesis testing using F test or two way analysis of variance, it is shown that Fcount $=0.08<$ Ftabel $=4.20$ then $\mathrm{H} 0$ is accepted and $\mathrm{H} 1$ is rejected, it means no interaction between modeling technique and motivation learning in influencing the ability to write student news text. As Irianto (2004: 232) discloses that an interaction occurs when the effects of one factor depend on the other factor in influencing something. This means that each factor between learning techniques (tourism and conventional works) with student learning motivation (high and low) are interrelated in each other in influencing students' news text writing skills.

\section{Conclusions}

Based on data analysis and discussion, it can be concluded that modeling technique influence the result of learning skill of writing news text. The result of research can be concluded that, firstly, there is difference of result of writing skill of news text of student which is taught by modeling technique with result of writing skill of news text of student taught by conventional technique. The test results of students' text-reading skills are taught using modeling techniques better than students taught using conventional learning techniques. This is due to the treatment provided using modeling techniques has advantages such as, the students are better able to pour ideas, ideas, and knowledge with the help on the stages in modeling techniques. Secondly, there are differences in the result of writing skill of news text of students who have high learning motivation with students who have low learning motivation. The result of writing skill of news text of students who have higher learning motivation is higher than students who have low learning motivation. Third, there is no interaction between modeling techniques and learning motivation in influencing the learning achievement of students' text writing skills. Furthermore, students who have high or low learning motivation can be taught by using modeling techniques. So, modeling techniques and learning motivation affect the skills of writing news text students.

Based on the results of research and conclusions, can be given suggestions as follows. To Indonesian language teachers, to apply modeling techniques to writing lessons, especially the skills to write news text on learning Indonesian. The next researcher, in order to investigate more deeply about the use of this modeling technique on other subjects or other subjects, especially those related to reading and writing. For students, to develop the potential of learning motivation that exists in karna with a motivation to learn can support success in writing. 


\section{Acknowledgments}

In the implementation of research and preparation of this article, the authors get a lot of help and guidance from various parties. On this occasion the author would like to thank sincerely to: Prof. Dr. Harris Effendi Thahar, M.Pd As Advisor I and Dr. Irfani Basri, M.Pd As Advisor II, and Examiner: Dr. Erizal Gani, M.Pd, Prof. Dr. Mudjiran, M.S. Kons, and Prof. Dr. Mudjiran, M.S. Kons.

\section{References}

Allen, M. J., dan Yen, W. M. (1979). Introduction to Measurement Theory. California: Brooks/Cole Publishing Company.

Andheska, H. (2016). "Membangun motivasi belajar siswa dalam pembelajaran menulis dengan memanfaatkan media pembelajaran inovatif". Program Studi Pendidikan Bahasa dan Sastra Indonesia, Universitas Maritim Raja Ali Haji. Bahastra, Oktober 2016, Volume XXXVI, Nomor 1.

Baer, J., Baldi, S., Ayotte, K., \& Green, P. J. (2007). “The reading literacy of US fourth-grade students in an international context: results from the 2001 and 2006 progress in international reading literacy study (PIRLS)." Washington, DC: National Center for Education Statistics, Institute of Education Sciences, U.S. Department of Education.

Barton, D., Hamilton, M., \& Ivanic, R. (2000). Situated Literacy, Reading and Writing in Context. London: Rotlegde.

Brady, E. R. (1972). The Effectiveness of Field Trips Compared to Media in Teaching Selected Environmental Concepts. USA: Iowa State University.

Burks, C.G. (2005). "Combating the bartleby syndrome with synectics: examining teacher attitude and the influences on student writing". Dissertation, Houston: Faculty of The College of Education, University of Houston.

Deshpande, S. (2014). "Teaching writing skills in English: involvement of students in the assessment and correction of their own errors". International Journal of English Language Teaching, Vol.3, No.1, pp. 68-73, March 2014.

Elly, W. B. (1992). How in The World do Students Read, IEA Study of Reading Literacy. Hamburg: The International Association for the Evaluation of Education Achivement.

Fernandes. A. S. (2012). "Writing to learn writing skills - a case study". European Journal of Engineering Education, Vol. 37, No. 2, May 2012, 179-192.

Gendrop, S. C. (1996). "Effect on intervention in synectics on the creative thinking of nurse." Creativity Research Journal, 9, 1, 11-19.

Gould, E. et al. (1989). The Educated Child. New York: The Free Press.

Graham, S., Bollinger, A., Olson, C. B., D'Aoust, C., McCutchen, D., \& Olinghouse, N. (2012). "Teaching Elementary School Students to be Effective Writers: a Practice Guide". NCEE 20124058. What Works Clearinghouse.

Irianto, A. (2004). Statistik Konsep Dasar dan Aplikasinya. Jakarta: Perdana Media.

Joni, T. R. (1992). "Memicu perbaikan pendidikan melalui kurikulum". Basis, No.07-08, 49, 41-48.

Kilgour, M. (2006). "Improving the creative process: analysis of the effect of divergent thinking techniques and domain specific knowledge on creativity". International Journal of Business and Society, 7, 2, 79-107.

Kotseas., E., \& Hashemi, R. (2017). "Asian students' challenges in writing with confidence". NYS TESOL JOURNAL, Vol. 4, No. 2 July 2017.

Lavie Alon, N., \& Tal, T. (2015). "Student self-reported learning outcomes of field trips: The pedagogical impact". International Journal of Science Education, 37(8), 1279-1298. 
Lie, A. (2004). Cooperative Learning, Memperaktikkan Cooperative Learning di Ruang-ruang Kelas. Jakarta: Gramedia.

Mattisson Ekstam, J. (2015). "Cultural and academic meetings in the writing classroom: China and the West". Sino-US English Teaching, April 2015, Vol. 12, No. 4, 241-249.

Munandar, U. (2004). Pengembangan Motivasi belajar Anak Berbakat. Jakarta: Asdi Mahasatya.

Nawi, N. F. dan Azmi, A. F. (2016). "An assessment of the effectiveness of field trips as a teaching and learning strategy: a case study of field trip to the parliament". Journal of Academia UiTM Negeri Sembilan 4 (2016) 1-11.

Negari, G. M. (2011). A study on strategy instruction and EFL learners' writing skill. International Journal of English Linguistics, 1(2), 299.

Rababah, L. M., Mohamed, A. H. B., Jdaitawi, M. T., \& Melhem, N. Z. B. (2013). "The level of creativity in english writing among jordanian secondary school students". Arts and Design Studies www.iiste.org ISSN 2224-6061 (Paper) ISSN 2225-059X (Online) Vol.10, 2013.

Rahmawati, D.L. (2013). "Penerapan teknik karyawisata dalam pembelajaran menulis karya sastra (berita)". Tenaga Pengajar pada Program Studi PGSD FKIP Universitas Muhammadiyah Palangkaraya Anterior Jurnal, Volume 13 Nomor 1, Desember 2013, Hal 43 - 51.

Republika. (2014). Keterampilan menulis siswa Indonesia rendah, (Online), (http://republika.com, diakses 10 September 2017).

Sugiyono. (2012). Teknik Penelitian Pendidikan Pendekatan Kuantitatif, Kualitatif, dan R\&D. Bandung: Alfabeta.

Supriadi, D. (1994). Motivasi belajar, Kebudayaan, dan Perkembangan IPTEK. Bandung: Alfabeta.

Supriyoko. (2004). Kebangkitan pendidikan kita. Kedaulatan Rakyat, 26 Mei 2004, hlm. 12.

Suryabrata, S. (2011). Metodologi Penelitian. Jakarta: Raja Grafindo Persada.

Suwanda. (2011). Desain Eksperimen untuk Penelitian Ilmiah. Bandung: Alfabeta.

Teo, T. dan Tan, A. (2006). "The use of Biyu in students creative writing: a study on an intervention program". The Korean Journal of Creative Thinking, 3, 1, 30-39.

Winskel, H. (2013). "Reading and writing in Southeast Asian languages". Procedia - Social and Behavioral Sciences, 97 ( 2013 ) $437-442$.

Zulaikhoh, S. (2009). Penerapan teknik field trip untuk meningkatkan kemampuan menulis deskripsi pada siswa kelas X-1 SMA Negeri 1 Ngemplak Kabupaten Boyolali. Skripsi. Jurusan Pendidikan Bahasa Sastra Indonesia dan Daerah, Fakultas Keguruan dan Ilmu Pendidikan, Universitas Muhammadiyah Surakarta. 